\title{
Profile of Domestic Violence Cases Examined At Langsa Hospital in 2019-2020
}

\author{
Rahmadsyah $^{\mathrm{a}}$, Doaris Ingrid Marbun ${ }^{\mathrm{b}}$ \\ Netty Herawatic
}

${ }^{a}$ rahmadsyah2485@yahoo.co.id

bingrid.posmen@gmail.com

cdokternetty@gmail.com

\author{
Department Forensic and Medicolegal, Faculty of Medicine, Universitas Sumatera Utara/ \\ RSUP H. Adam Malik \\ Jl. Bunga Lau no. 17 Medan 20136, Indonesia
}

\begin{abstract}
Domestic violence (KDRT) is one type of violence that is a global health problem ${ }^{1}$. Studies from various countries show that the incidence of domestic violence ranges from 15-71 percent ${ }^{2}$. In the 2011 National Commission on Violence Against Women's annual records, the most victims of domestic violence were women in the productive age range (25-40 years) ${ }^{3}$. The purpose of this study was to determine the profile of cases of Domestic Violence examined at Langsa Hospital in 2019 - 2020. This study is a descriptive study. The sample in this study was all post-mortem et repertum data on cases of domestic violence examined at the Forensic and Medicolegal Installation at Langsa Hospital in 2019 to 2020, totaling 21 cases. The conclusion from the results of this study was that the percentage of domestic violence cases in 2019 was $47.61 \%$ (10 cases), in 2020 it was 52.39\% (11 cases). The largest percentage of domestic violence cases was in victims aged 18-65 years, which was $76,20 \%$ (16 cases). The smallest percentage of domestic violence cases was in victims aged $80-99$ years and $>100$ years, namely $0 \%$ ( 0 cases). The largest percentage of domestic violence cases was in female victims, which was $71.42 \%$ (15 cases). The lowest percentage of domestic violence cases was male victims, namely $28.58 \%$ (6 cases). The largest percentage of domestic violence cases was $47.62 \%$ (10 cases). The smallest percentage of domestic violence cases among victims who work as private employees is $4.77 \%$ (1 case). The largest percentage of domestic violence cases was in victims with wife status, which was $47.62 \%$ (10 cases). The smallest percentage of domestic violence cases in victims with husband status is $4.77 \%$ ( 1 case).
\end{abstract}

Keywords: Domestic Violence; Profile; Visum et Repertum

\section{Introduction}

Domestic violence according to the PKDRT Law no. 23 of 2004 is any act against a person, especially a woman, which results in physical, sexual, psychological misery or suffering, and/or neglect of the household, including threats to commit acts of coercion, or unlawful deprivation of liberty within the scope of the household1. The scope of household as intended in Law Number 23 of 2004 concerning Elimination of Domestic Violence, Chapter 1 concerning General Provisions Article 2 covers husband, wife, children, people who have relationships with husbands, wives, and children because of blood relations, marriage, breastfeeding, parenting, and guardianship who stay in the household, and or people who work to help the household and stay in the household. A household with a nuclear family only consists of a husband, a wife, and children. It is also common in society that a household consists of other family members such as in-laws, in-laws, and relatives on the basis of blood ties or marriage with the husband and wife concerned. In addition, households in modern life in urban areas are generally enlivened again by the presence of other people who act as helpers. The maid can come from relatives or families of the husband and wife concerned and can also be outsiders. Behavior or acts of domestic violence as a social fact are not new from the sociological perspective of Indonesian society. This problem has been around for a long time and is still ongoing today. Domestic violence as referred to in Law Number 23 of 2004, Chapter 1 IJRP 2022, 93 (3), 485-409. Goi Provisions Article 2 is any act against a person, especially a woman, which results in physical, Sexual, psychological misery or suffering, and/or neglect of the household. including threats to comminit acts, coercion, or deprivation of liberty against the law within the scope of the household. Domestic violence is also an antisocial behavior that harms a member or a number of members in the household from a physical, psychological or economic perspective. The classification into a crime is not because the act is anti-social but because it contains 
a malicious intent (mens rea) which can result in physical and non-physical harm to the victim which is prohibited by criminal law.

\section{2. $\quad$ Research Method}

This research is a descriptive study that aims to determine the profile of cases of Domestic Violence examined at Langsa Hospital in 2019 - 2020. This research was conducted at the Forensic and Medicolegal Installation of Langsa Hospital in Langsa City. This research was conducted from September 2021 to January 2022 which includes submitting titles, literature studies, reading proposals, collecting and processing data as well as writing and reporting research results. The population in this study were all cases of Domestic Violence examined at the Forensic and Medicolegal Installation of Langsa Hospital in Langsa City in 2019 to 2020, totaling 295 cases. The sample in this study was all post-mortem et repertum data on cases of domestic violence examined at the Forensic and Medicolegal Installation at Langsa Hospital in 2019 to 2020, totaling 21 cases. The research sample was obtained from all visum et repertum data at the Forensic and Medicolegal Installation of Langsa Hospital in cases of Domestic Violence in Langsa City in 2019 to 2020 with a total sampling method of 21 cases. The variables in this study were: age, gender, occupation, relationship between victim and perpetrator. Data was collected using secondary data, namely all visum et repertum data at the Forensic and Medicolegal Installation of Langsa Hospital in the case of Domestic Violence and the data listed the variables to be studied according to the specific objectives of this study. Data were collected and recorded and tabulated with the types of variables to be studied. This research has been approved by the Ethics Committee of the Faculty of Medicine, University of North Sumatra, Medan NO:1189/KEP/USU/2021.

\section{Results}

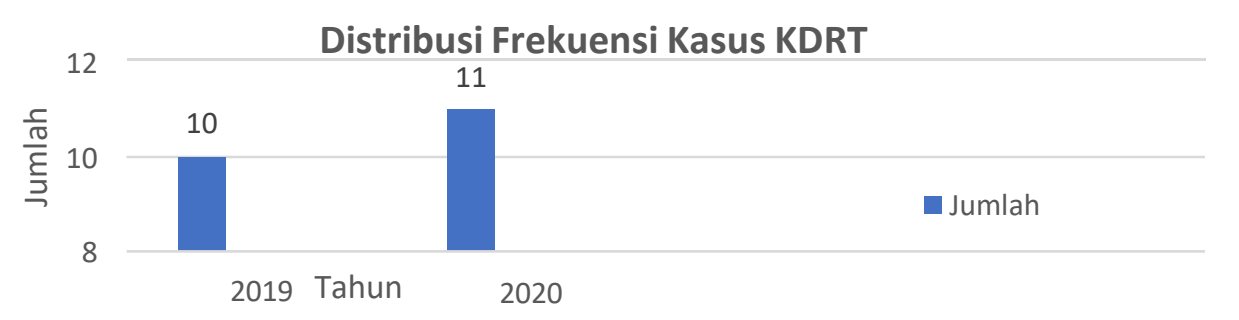

Figure 1. Frequency Distribution of Domestic Violence Cases

Based on the diagram above, it is known that the distribution of domestic violence cases in 2019 was 10 cases, in 2020 there were 11 cases.

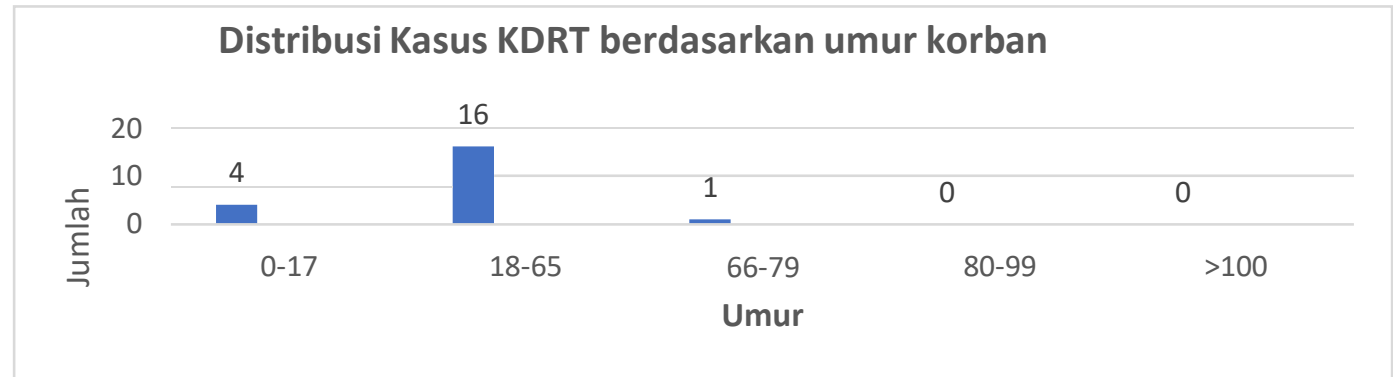

Figure 2. Distribution of Domestic Violence Cases based on the age of the victim

Based on the diagram above, it is known that the cases of domestic violence in victims aged 0-17 years were 4 cases, aged 18-65 years were 16 cases, aged 66-79 years were 1 case. Cases in victims aged 80-99 years and >100 years are 0 cases. 


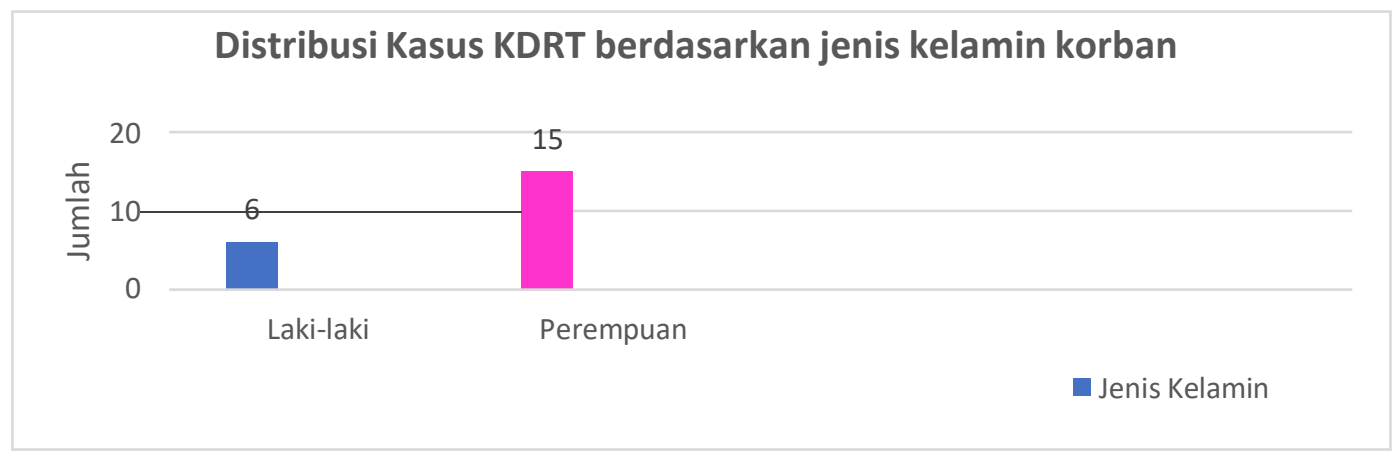

Figure 3. Distribution of Domestic Violence Cases by Gender of Victims

Based on the diagram above, it is known that there were 15 cases of domestic violence in female victims. There were 6 cases of domestic violence in male victims.

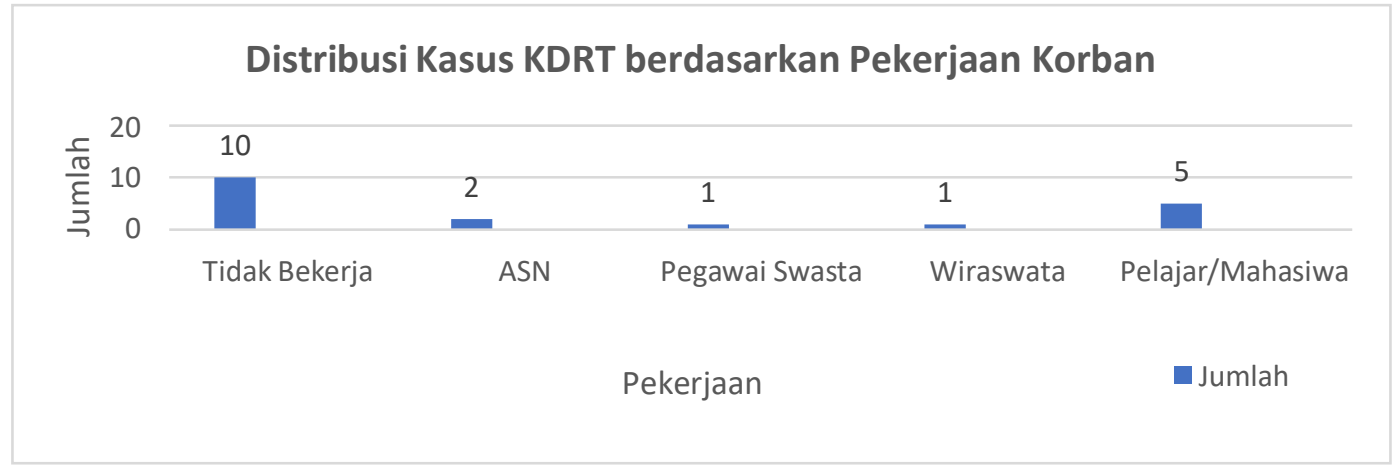

Figure 4. Distribution of Domestic Violence Cases by Victim's Occupation

Based on the diagram above, it is known that there are 10 cases of domestic violence in victims who do not work, 1 case for victims who work as ASN, 1 case for victims who work as private employees, 3 cases for victims who work as entrepreneurs, 3 cases for victims who work as Students / Students, namely 5 cases.

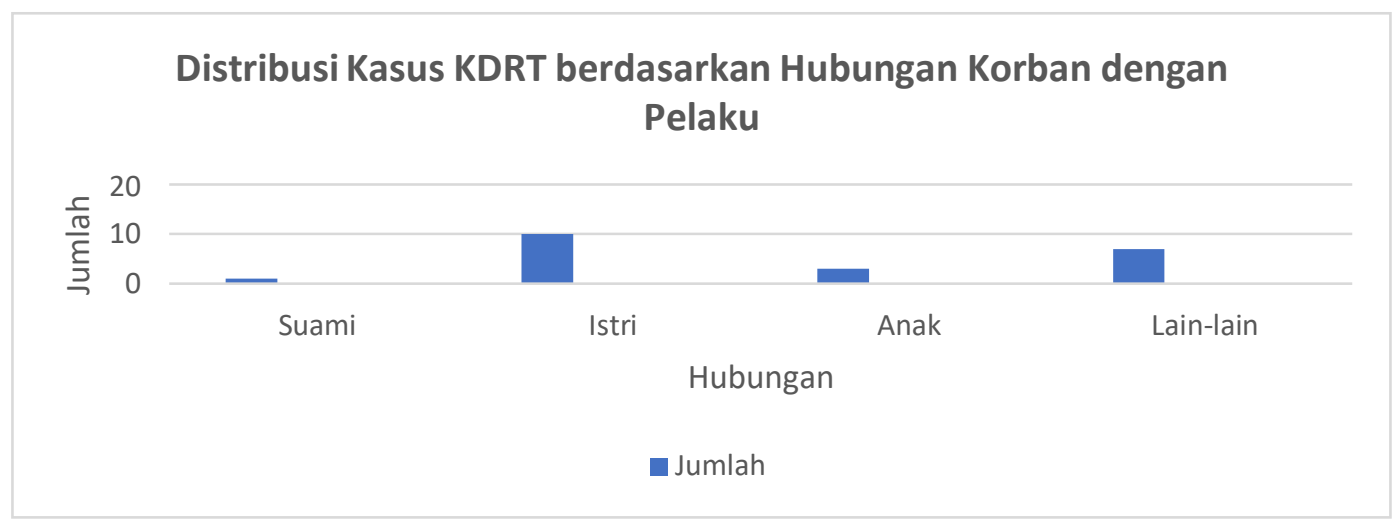

Figure 5. Distribution of Domestic Violence Cases by Relationship of Victims with Perpetrators

Based on the diagram above, it is known that the case of domestic violence among victims with husband status is 1 case, wife's status is 10 cases, child status is 3 cases and other relationships are 7 cases.

\section{Discussion}

The percentage of domestic violence cases in 2019 was $47.61 \%$, in 2020 it was $52.39 \%$. Domestic violence is a type of violence that is a global health problem. 1 Studies from various countries show that the incidence of domestic violence ranges from 15-71\%.2 In Indonesia, cases of violence against women tend to increase. The number of cases of violence in 2010 increased about 5 times compared to 20064. The highest percentage of 
domestic violence cases was among victims aged 18-65 years, which was $76.20 \%$ (16 cases). The lowest percentage of domestic violence cases was in victims aged $80-99$ years and $>100$ years, namely $0 \%$ ( 0 cases). This result is in accordance with the research conducted by Dedy Afandi et al in 2012 which stated that domestic violence was mostly experienced by women of productive age, namely 19-30 years (38\%) and 31-40 years (39.2\%), with the majority of victims being housewives. stairs (IRT) which is $83.5 \%$. These results are consistent with research in Singapore, Hong Kong and reports from the National Commission on Violence against Women. The range of figures from the above study is between 21-40 years4. The highest percentage of domestic violence cases was female victims, which was $71.42 \%$ ( 15 cases). The lowest percentage of cases of domestic violence among male victims was 28.58\% (6 cases). This result is in accordance with Dedi Afandi et al in 2012 concluding that the most victims of domestic violence are women. Reports from various studies always show women as the majority of victims in cases of domestic violence. Gender issues, patriarchal socio-cultural factors, the level of economic dependence of women, and the low level of community understanding are factors that cause the dominance of women as victims of domestic violence4. The highest percentage of cases of domestic violence among victims who do not work is $47.62 \%$ (10 cases). The smallest percentage of domestic violence cases among victims who work as private employees is $4.77 \%$ ( 1 case). The results in this study are in line with previous research by Hasnerita in 2012 which concluded that based on the results of research the relationship between wife's work and domestic violence was more in wives who did not work with severe physical violence as much as $97 \%$, compared to wives who did not work with violence. mild physical violence only $3 \%$. This is in accordance with the theory which says that the wife's dependence on the economy in terms of the husband forces the wife to comply with all the wishes of her husband even though he feels suffering. In fact, even if harsh measures are taken against him, he will not report his suffering with consideration for his survival and the education of his children. This is used by the husband to act arbitrarily to his wife10. The largest percentage of domestic violence cases was in victims with wife status, which was $47.62 \%$ (10 cases). The smallest percentage of domestic violence cases in victims with husband status is $4.77 \%$ ( 1 case). The results of this study are in line with research by Mery Ramadani in 2015 , which found that $55.9 \%$ of husbands committed domestic violence against their wives. This shows the high incidence of violence against women in the domestic sphere. The National Commission for the Protection of Women also noted that the incidence of domestic violence tends to be high and increases every year, with an average increase of 5-10\% per year.

\section{Conclusion}

Based on the results of this study, it can be concluded: The percentage of domestic violence cases in 2019 was $47.61 \%$ ( 10 cases), in 2020 it was $52.39 \%$ (11 cases). The largest percentage of domestic violence cases was in victims aged $18-65$ years, which was $76.20 \%$ ( 16 cases). The lowest percentage of domestic violence cases was in victims aged $80-99$ years and $>100$ years, namely $0 \%$ ( 0 cases). The highest percentage of domestic violence cases was female victims, which was $71.42 \%$ ( 15 cases). The lowest percentage of cases of domestic violence among male victims was $28.58 \%$ ( 6 cases). The highest percentage of cases of domestic violence among victims who do not work is $47.62 \%$ (10 cases). The smallest percentage of domestic violence cases among victims who work as private employees is $4.77 \%$ ( 1 case). The largest percentage of domestic violence cases was in victims with wife status, which was $47.62 \%$ (10 cases). The smallest percentage of domestic violence cases in victims with husband status is $4.77 \%$ ( 1 case).

\section{Suggestions}

The need for socialization to the public about domestic violence so that victims of domestic violence report to the authorities about what they have experienced. Health workers can continue to treat victims who experience domestic violence with appropriate treatment, both for physical and psychological violence. It is recommended that there be a special post in the hospital that immediately receives complaints from victims of domestic violence who come directly to the hospital before reporting to the authorities.

\section{Acknowledgments}

We would like to thank the Chief of RSUD Langsa and Chief of Forensic and Medicolegal Installation RSUD Langsa. 


\section{References}

1. Manan MA. Kekerasan Dalam Rumah Tangga Dalam Perspektif Sosiologis. Jurnal Legislasi, 2008 September: 5(3):p.66-77.

2. Karya D. Tindak Pidana Kekerasan Dalam Rumah Tangga Yang Dilakukan Suami Terhadap Istri (Studi Kasus Di Pengadilan Negeri Gresik). DIH, Jurnal Ilmu Hukum Fakultas Hukum Universitas 17 Agustus 1945 Surabaya, 2013 Februari: 9(17):p.35-46.

3. Sofwan D. Ilmu Kedokteran Kehakiman. Semarang. 2000. p.126- 133.

4. Afandi D, Rosa WY, Suyanto, Khodijah, Widyaningsih C. Karakteristik Kasus Kekerasan dalam Rumah Tangga. J Indon Med Assoc, 2012 November:62(11):p.435-438.

5. Idris AM, Tjiptomartono, Legowo A. Penerapan Imu Kedokteran Forensik Dalam Proses Penyidikan. Edisi Revisi. Jakarta. 2008. p. 113- 132.

6. Budianto A. Widiatmika W. Sudiono S. Winardi T. Ilmu Kedokteran Forensik. FK-UI. Jakarta. 1997. p. 147158.

7. Undang-Undang Nomor 23 tahun 2004 tentang Penghapusan Kekerasan Dalam Rumah Tangga.

8. Hamdani N. Ilmu Kedokteran Kehakiman. Edisi Kedua. Jakarta.1972. p.174- 179.

9. Ramadani M, Yuliani F. Kekerasan Dalam Rumah Tangga (KDRT) Sebagai Salah Satu Isu Kesehatan Masyarakat Secara Global. Jurnal Kesehatan Masyarakat Andalas. 2015 April : 9(2):p.80-87.

10. Hasnerita, Hubungan Antara Umur, Pendidikan, Pekerjaan Terhadap KDRT Yang Dilakukan Oleh Suami Terhadap Istri Di Salah Satu Rumah Sakit, Journal STIKIM, 2013. 